Bu makaleye atıfta bulunmak için/To cite this article:

KASAP, M. AKMEŞE, H. (2021). Bir Paydaş Olarak Turizm İşletmesi Çalışanlarının Kurumsal Sosyal Sorumluluk

Algılarının İncelenmesi. Atatürk Üniversitesi Sosyal Bilimler Enstitüsü Dergisi, 25 (Özel Sayı), 153-168.

\title{
Bir Paydaş Olarak Turizm İşletmesi Çalışanlarının Kurumsal Sosyal Sorumluluk Algılarının İncelenmesi
}

\author{
Mehmet $\operatorname{KASAP}^{(*)}$ \\ Halil AKMEŞE ${ }^{(* *)}$
}

Öz: Bu araştırma kurumsal olan konaklama, yiyecek-içecek ve seyahat işletmelerinde çalı̧̧anların çalıştıkları işletmelerin bir paydaşı olarak kurumsal sosyal sorumluluk algılarını değerlendirmek amacıyla yapılmıştır. Tanımlayıcı ve kesitsel nitelikte olan bu araştırma Ocak 2021 ile Nisan 2021 tarihleri arasında 152 turizm işletmesi çalışanı ile gerçekleştirilmiştir. Araştırmada çevrimiçi anket yöntemi kullanılmıştır. Araştırmada katılımcıların sosyal sorumluluk algılarının orta düzeyde olduğu tespit edilmiştir. Katılımcılar çalıştıkları işletmede kültürel ve sosyal sorumluluk faaliyetlerinin yetersiz olduğunu ayrica işletmenin iş görenler için yetersiz sosyal faaliyet yaptığını ifade etmiştir. Katılımcıların çoğunluğunun KSS kavramı hakkında bilgisinin olmadı̆̆l, aylık gelir arttıkça özellikle iş gören faktörü başta olmak üzere KSS algısının arttığı tespit edilmiştir. Bu doğrultuda bu işletmelerin paydaş temelli kurumsal sosyal sorumluluk faaliyetlerini arttırmaları ve çalışanlarına da bu hususta eğitim ve bilgiler vermeleri gerektiği sonucuna varllmıştır.

Anahtar Kelimeler: Turizm, paydaş, kurumsal sosyal sorumluluk, çalışan.

\section{Investigation of Corporate Social Responsibility Perceptions of Tourism Business Employees As a Stakeholder}

Abstract: This research was carried out in order to evaluate the perceptions of corporate social responsibility as a stakeholder of the enterprises in which they work in institutional accommodation, food and beverage and travel enterprises. This descriptive and cross-sectional study was conducted with 152 business employees between January 2021 and April 2021. The online survey method was used in the research. In the study, it was determined that the social responsibility perceptions of the participants were moderate. Participants stated that cultural and social responsibility activities are insufficient in the enterprise they work in and that the enterprise does insufficient social activities for the employees. It has been determined that the majority of the participants do not have knowledge about the concept of CSR, and as the monthly income increases, the perception of CSR increases, especially the employee factor. In this direction, it has been concluded that these enterprises should increase their stakeholder-based corporate social responsibility activities and provide training and information to their employees in this regard.

Keywords: Tourism, stakeholder, corporate social responsibility, employee.

\footnotetext{
${ }^{*}$ Doktora Öğrencisi, Necmettin Erbakan Üniversitesi Sosyal Bilimler Enstitüsü Turizm İşletmeciliği Anabilim Dalı (e-posta: m.kasap8461@gmail.com) (D) ORCID ID. https://orcid.org/0000-0001-9112-0101

${ }^{* *)}$ Doç. Dr. Necmettin Erbakan Üniversitesi Turizm Fakültesi (e-posta: halilakmese@ gmail.com) (D) ORCID ID. https://orcid.org/0000-0003-4694-2215
} 
Makale Geliş Tarihi: 07.06.2021

Makale Kabul Tarihi: 20.09.2021

DOI:10.53487/ataunisosbil.948820

\section{Giriş}

Küreselleşen dünya ile birlikte günümüzde işletmelerden sadece müşterilerinin ihtiyaç ve isteklerini karşılaması değil; etkileşimde bulunduğu çevreye, toplumsal ve sosyal konulara duyarlılık göstermesi de beklenmektedir (Akkoyunlu ve Kalyoncuoğlu, 2014: 125; Akbaş-Tuna, Özkara ve Taş, 2019: 265). İşletmelerin toplumsal, sosyal ve çevresel konulara önem vermesi ise kurumsal sosyal sorumluluk (KSS) ile mümkün olmaktadır. Kurumsal sosyal sorumluluk işletmelerin topluma faydalı, toplumun değerleri ve hedefleri doğrultusunda sosyal sorumluluk faaliyetleri konusunda yükümlü olmaları şeklinde açıklanmaktadır (Kakabadse, Rozuel ve Lee-Davies, 2005: 278). KSS; modern yönetim anlayışının önemli bir parçasıdır ve iş ahlakı, iş etiği, adaletin sağlanması, kurum içinde ve kurumlar arasındaki ahlaki davranışlar ile ilgilenmektedir (Güven, 2016: 140; Önder ve Kaya, 2018: 156). Günümüzde işletmelere kurumsal sosyal sorumluluk çerçevesinde hizmet vermeleri önerilmektedir (Baniya, Thapa ve Kim, 2019: 2771; Akbaş-Tuna, Özkara ve Taş, 2019: 265). Zira günümüzde; kurumsal sosyal sorumluluğu etkili kullanabilen işletmeler nispi olarak ekonomik yönden daha düşük risk taşımakta, yatırımcıların ilgisini çekmekte ve güven ortamı yaratmaktadır (Becan, 2011: 22).

İşletmeler kurumsal sosyal sorumluluk çerçevesindeki uygulama ve faaliyetleri yaparken paydaşlara ihtiyaç duymaktadır. Bir işletmenin paydaşlarını "hissedarlar", "yatırımcılar", "tedarikçiler", "iş görenler", "müşteriler", "rakipler", "toplum" ve “devlet kurumları" oluşturmaktadır. İşletmeler ve paydaşlar arasında çift yönlü bir ilişki bulunmakta ve sürekli iletişim sağlanarak etkileşim oluşmaktadır (Akbaş-Tuna, Özkara ve Taş, 2019: 265).

İşletmelerin yenilikçi ve farklı olma yollarından biri olan KSS çok sayıda sektörde ele alınmaya başlamıştır. Çünkü işletmeler sadece kâr etme amacı güttüklerinde bazı şeylerin yolunda gitmediğini deneyimlemiş ve gelişmenin KSS ile mümkün olacağını görmüşlerdir (Becan, 2011: 18). Turizm sektörü de rekabetin oldukça sert yaşandığı, yenilikleri takip etmeyi gerektiren, emek-yoğun ve dinamik bir meslek grubu olmasından dolayı paydaş temelli kurumsal sosyal sorumluluğa ihtiyaç duyan sektörlerden biridir. Ayrıca turizm sektörü; doğa tahribatı, çevre kirliliği ve iklim değiş̧ikleri gibi birçok sorunla karşılaşmaktadır. Dolayısıyla bu sorunlar da, turizm işletmelerini sosyal sorumluluğa iten nedenler arasındadır (Avcı ve Akdemir, 2014: 126).

Turizm, söktörü insan temelli bir hizmet sunmaktadır. Çalışanlar, turizm sektörünün en önemli hizmet öğesini oluşturmaktadır. Çalışanların memnuniyetsizliği hizmet kalitesini doğrudan etkileyebilmektedir. Dolayısıyla çalışanların motivasyonunun ve iş doyumunun işletmeler tarafından yüksek tutulması gerekmektedir (Avcı ve Akdemir, 2014: 127). Paydaş temelli kurumsal sosyal sorumluluk kapsamında işletmeler; personellerinin sağlığını ve iş güvenliğini sağlamalı, liyakat ilkelerini uygulamalı, özel yaşamlarına saygı göstermeli ve iş hayatından memnuniyet sağlamaları için gerekli 
Bir Paydaş Olarak Turizm Ișsletmesi Çalışanlarının Kurumsal Sosyal Sorumluluk Algilarının İncelenmesi

önlemleri almalıdır (Brunton, Eweje ve Taskin, 2015: 5). Turizm sektöründe kurumsal sosyal sorumluluğu inceleyen çalışmalara bakıldığında; kurumsal sosyal sorumluluğun müşteri memnuniyetinde olumlu etkisinin olduğunu (Kim, Kang ve Mattila, 2012: 44), turizm işletmelerinin kârlılığını artırdığını (Tsai, Tsang ve Cheng, 2012: 1145) belirten çalışmalar bulunmaktadır. Ayrıca kurumsal sosyal sorumluluk çerçevesinde etik davranımların iş doyumunu olumlu yönde etkilediği (Lee vd. 2012: 754), işte kalma niyetini artırdığı (Çalışkan ve Ünüsan, 2011: 164-165) tespit edilmiştir.

Başarılı bir biçimde kurumsal sosyal sorumluluk uygulamalarını yerine getiren turizm işletmelerinde, hem personelin hem de müşterilerin memnuniyeti sağlanacak, işletmelerin imajı, kurumsal itibarı ve işletme faaliyetlerinin sürdürülebilirliği artacaktır (Paskova ve Zelenka, 2019: 534; Jogdand, Sawant ve Ragde: 596; Su ve Swanson, 2017: 309; Çalışkan ve Ünüsan, 2011: 155; Henderson, 2007: 231; Tsai, Tsang ve Cheng, 2012: 1144). Kurumsal sosyal sorumluluk çerçevesinde hizmet anlayışına sahip ve turizm sektörünün öncü işletmelerinden olan ve sürdürülebilirliği sağlamayı başaran Hilton, Starwood, Choice Hotels, Starbucks ve McDonald's örnek gösterilebilir (Kang, Lee ve Huh, 2010: 72).

Turizm literatürüne bakıldığında çalışmalarda kurumsal sosyal sorumluluk kavramının incelendiği (Yorulmazer ve Doğan, 2017; Sağır ve Türkeli, 2015; GülÖzdoğan ve Çolakoğlu, 2018; Boğan, Ulama ve Sarışık, 2016) ancak paydaş temelli kurumsal sosyal sorumluluğun yeterince ele alınmadığı görülmektedir. Oysaki turizm emek yoğun bir sektör olduğu için işletmelerin bir paydaşı olan çalışanların da KSS algılarının değerlendirilmesi gerekmektedir. Bu bilgiler ışı̆̆ında araştırmanın amacı; günümüzde turizm işletmeleri için bir gereklilik olan kurumsal sosyal sorumluluk kavramının, işletmelerin en önemli paydaşlarından olan işletme çalışanları tarafından ne derecede algılandığının tespitini yapmaktır. Bu doğrultuda, Karadeniz Bölgesinin önemli turizm şehirlerinden biri olan Trabzon ilindeki turizm işletmelerinde çalışanların kurumsal sosyal sorumluluk algıları incelenmiş ve önerilerde bulunulmuştur. Ayrıca çalışmada paydaş temelli kurumsal sosyal sorumluluk kavramının turizm literatüründeki yerini vurgulamak ve bu konuda farkındalık oluşturmak amaçlanmıştır.

\section{Literatür Taraması}

\section{A. Kurumsal Sosyal Sorumluluk (KSS) ve Paydaş Teorisi}

Akademik olarak kabul edilen ilk KSS tanımı, 1953 yılında Howard Bowen'ın "İş adamlarının Sosyal Sorumlulukları" (Social Responsibilities of the Businessman) kitabında yapılmıştır (Nikolova ve Arsić, 2017: 26). Bu tanımda, iş adamlarının topluma faydalı olan, toplumun değerleri ve hedefleri doğrultusunda sosyal sorumluluk faaliyetleri konusunda yükümlü oldukları belirtilmektedir. İlk tanımın Bowen tarafından yapılmasının ardından ise bu kavram ile ilgili birçok bilim insanı farklı tanımlar ileri sürmüştür. Örneğin, Friedman 1962'de KSS'yi “İşletmelerin tek bir sosyal sorumluluğu ve bu sorumluluğun da aldatma veya dolandırıcılık olmadan, serbest ve açık bir rekabete dayalı şekilde kurallar dâhilinde maddi kaynakları kullanarak kârı arttırmak için yapılan faaliyet olduğu" şeklinde tanımlamaktadır. Baker (2003)'a göre KSS, şirketlerin iş süreçlerini nasıl yönettiğiyle ilgilidir (Kakabadse, Rozuel ve Lee-Davies, 2005: 281). KSS'de amaç, işletmelerin yalnızca kendi çıkarlarını gözetmekten ziyade toplumun 
çıkarlarına da hizmet etmek, sosyal problemleri çözmek, temiz bir çevre yaratmak, sosyal hareketlere gönüllü şekilde katılmak, sosyal hareketleri destekleyen bir imaj yaratmaktır (Isma1l, 2009:199, Becan, 2011: 18; Taghian, D'Souza ve Polonsky, 2015: 341).

KSS, işyeri ve işçi sorunları, iş sağlığı ve güvenliği, insan hakları, tüketici sorunları ve çevre problemleri gibi sorunlar ile ilgilenmektedir (Aktan, 2007: 7). Ayrıca KSS'ye göre işletmelerin eğitim ve kültürel alanda da sorumlulukları bulunmaktadır (Becan, 2011: 22). KSS'nin kurumsal itibarı etkilediği ve bunun sonucunda da iş performansını arttırdığı belirtilmektedir (Miles ve Munilla, 2004: 2; Zink, 2005: 1042). Eğer işletmeler tarafindan sosyal sorumluluk üstlenilmezse, toplum ve çevrede işletmelerin sürekli kapitalist hırslarının tehlikeli sonuçları görülebilmektedir (Dennis, 2015: 176).

Turizm işletmelerinin paydaşları arasında; çalışanlar, turistler ve tedarik zinciri, hissedarlar, yatırımcılar, yerel topluluklar, hükümet yetkilileri, STK'lar ve medya yer almaktadır (Usta ve Pırnar, 2009: 10). Kurumsal sosyal sorumluluk kapsamında, müşterilerin istediği; güvenli ve kaliteli bir hizmet almaktır. İşletmelerin isteği; ödemelerini zamanında yapan, güvenilir müşteri ile çalışmaktır. Yerel halkın isteği; kurumun sosyal sorumluluğunun bulunmasıdır. Çalışanların isteği ise; adil, güvenilir çalışma ortamı ve değer görmektir.

\section{B. Kurumsal Sosyal Sorumluluk ve Turizm}

Günümüzde KSS, işletmelerin stratejilerini gerçekleştirmek ve uygulamak için ortak oldukları çok paydaşlı bir yaklaşım olarak görülmektedir. Turizm sektöründe paydaş temelli KSS; turizm işletmelerinin sosyal ve çevresel duyarlılıklarına, kendi iş misyonlarına, stratejilerine, operasyonlarına ve paydaşlarıyla etkileşimlerine entegre ettiği yönlendirici bir iş politikası olarak tanımlanabilmektedir (Sağır ve Türkeri, 2015: 292). Turizm şirketlerinin stratejilerinde KSS kavramı, merkezi bir parça haline gelmiştir (Lund-Durlacher, 2015: 59). Çevrenin korunması, çalışanlar için adil çalışma koşulları ve yerel toplulukların refahına katkıda bulunmak, uluslararası turizm şirketlerinin stratejilerindeki kilit konulardır.

Turizmde KSS'nin amaçları;

- Personel için sosyal koşulların geliştirilmesi ve iyileştirilmesi (eğitim ve mesleki gelişim, çalışanlara sosyal paketler, motivasyon, iş ve eğlence için uygun koşullar vb.)

- Çalışanların sağlığı ve güvenliği, turistlerin güvenliği (güvenli işyerleri, personel sağlık bakımı, turizm hizmetlerinin tüketicilere sunulması, dinlenme yerleri, kullanılmayan turlar için tazminat, vb.)

- Yerel destinasyonların geliştirilmesi (kültürel ve tarihi nesneler, eğitim ve spor tesisleri, hayır kurumu vb.)

- Çevre koruma ve sürdürülebilirlik (ekonomik ve dikkatli kullanım doğal kaynaklar, kirliliğin önlenmesi, etkin çevre yönetimi vb.) (Blinova vd., 2018: 638-639). 
Bir Paydaş Olarak Turizm Ișsetmesi Çalışanlarının Kurumsal Sosyal Sorumluluk Algilarının İncelenmesi

Turizm sektörü açısından bu amaçlar oldukça önem taşımaktadır. Son zamanlarda turizm sektöründe meydana gelen olumsuzluklar, destinasyonların ve doğal çevrenin yaşadığı tahribatlar ve turizm alanında bilinç düzeylerindeki artış ile bu sektörün de KSS'ye yöneldiği gözlenmektedir (Su ve Swanson, 2017: 308; Çakmak ve Aktan, 2018: 176). Turizm endüstrisinin varlığını sürdürebilmesi, değişimlere ve yeniliklere ayak uydurabilmesi için kâr etmek amaçlanmaktadır. Fakat yalnızca kâr etmeyi amaçlayan işletmelerin başarısız olma ihtimali yüksektir. Dolayısıyla turizm işletmelerinin, topluma hizmet etmeyi hedefleyerek girişimler yapması uzun ömürlü olmalarını sağlayacaktır (Türker ve Uçar, 2013: 156).

Turizm pazarının olumsuz etkilerinin tanınması ve bu etkilere katkılardan dolayı sorumluluk kabulü, turizm sosyal sorumluluğunun uygulama sürecinin arkasındaki itici güçleri temsil etmektedir. Bu itici güçler, hem talep tarafında hem de arz tarafında baskılara neden olmaktadır. Bu doğrultuda ziyaretçiler, yerel nüfusun yaşam kalitesini ve çevresini olumsuz etkilemeyen turizm ürünleri istemeye başlar. Aynı zamanda bazı tedarikçiler, yaşam kalitesini bozmayan malzemeler ve insan kaynakları seçmeye başlar. $\mathrm{Bu}$ baskılar, hem önleyici hem de tazminat tedbirlerinin uygulanması nedeniyle turizm pazarında değişikliklere neden olmaktadır. Turizm ürünleri daha sorumlu bir şekilde üretilir, dağıtılır ve işletilir. Bu da turizm sektörü için kurumsal sosyal sorumluluğu kaçınılmaz kılmaktadır (Paskova ve Zelenka, 2019: 541).

\section{Araştırmanın Yöntemi}

$\mathrm{Bu}$ araştırma tanımlayıcı ve kesitsel tipte planlanmış bir araştırma makalesidir. $\mathrm{Bu}$ doğrultuda aşağıdaki araştırma sorularına yanıt aranmıştır;

Araştırma soruları;

- Turizm işletmesi çalışanlarının toplam KSS algı düzeyi nedir?

- Turizm işletmesi çalışanlarının müşteriler, hissedarlar, iş görenler, toplum, yasa ve etik alt boyutlarındaki algı düzeyi nedir?

- Turizm işletmesi çalışanlarının sosyo-demografik özelliklerine göre KSS algıları arasında istatistiksel olarak anlamlı farklılık var mıdır?

Araştırma için öncelikle Necmettin Erbakan Üniversitesi Sosyal ve Beşeri Bilimler Bilimsel Araştırmalar Etik Kurulundan 19/02/2021 tarih ve 2021/100 sayılı etik kurul izni alınmıştır. Araştırma Helsinki Bildirgesi'ne uygun olarak Ocak 2021 - Nisan 2021 tarihleri arasında Trabzon şehrinde yer alan ve kurumsal olan 5 konaklama işletmesi, 15 yiyecek-içecek işletmesi ve 6 seyahat işletmesinde çevrimiçi anket yöntemiyle yapılmıştır. Araştırmaya katılma kriterleri arasında bulunduğu işletmede en az 1 yıldır çalışıyor olma, akıllı cep telefonuna sahip olma (anketlerin linki telefonlara atılmıştır), çalışmaya gönüllü olarak katılmayı kabul etme yer almaktadır. Bu doğrultuda toplam 152 kişiye ulaşılmıştır. Çalışma sonrası örneklemimizin yeterliliğini değerlendirmek için posterior güç analizi G. Power-3.1.9.2 programı kullanılarak yapılmış ve \%95 güven (1$\alpha$ ), \%95 test gücü (1- $\beta$ ) aralığında araştırmanın gücü \%71 olarak belirlenmişstir.

Araştırmada kullanılan anket iki kısımdan oluşmakta olup, birinci kısımda işletme çalışanlarına ait demografik bilgiler (cinsiyet, yaş, eğitim durumu, çalışılan işletme türü) 
yer alırken; ikinci kısımda ise "Paydaş Temelli Sosyal Sorumluluk Ölçeği" yer almaktadır. Ölçek 2013 yılında Perez ve arkadaşları tarafından geliştirilmiş (Stakeholder-Based Corporate Social Responsibility) Akbaş-Tuna vd. (2019) tarafından Türkçeye uyarlanmıştır. 22 maddeden oluşan ölçeğin; müşteriler, hissedarlar, iş görenler, toplum, yasa ve etik alt boyutları bulunmaktadır. Ölçek $5^{\prime}$ li likert tipinde olup $1=$ hiç katılmıyorum, $2=$ katılmıyorum, $3=$ orta düzeyde katıllyorum, $4=$ katıllyorum ve $5=$ tamamen katılıyorum şeklinde numaralandırılmaktadır. Ölçeğin Cronbach's alfa değerleri müşteriler; 0.84 , hissedarlar; 0.79 , iş görenler; 0.86 , toplum; 0.88 ve yasal ve etik alt boyutu; 0.78 ve tüm ölçek için 0.92 olarak hesaplanmıştır. Bu araştırmada ise müşteriler; 0.82 , hissedarlar; 0.79 , iş görenler; 0.92 , toplum; 0.90 ve yasal ve etik alt boyutu 0.74 ve tüm ölçek için 0.90 olarak tespit edilmiştir.

Verilerin değerlendirmesinde ilk olarak Kolmogorov Smirnov testi yapılmış ve verilerin normal dağılıma uygun olduğu belirlenmiştir $(\mathrm{p}>0.05)$. Bu doğrultuda, bağımsız iki grup karşılaştırmalarında "Bağımsız Örneklemler T Testi" ve bağımsız üç grup karşılaştırmalarında "ANOVA" testi kullanılmıştır. Anlamlı farklılığın tespiti için $\mathrm{p}<0.05$ kriteri dikkate alınmıştır. Çıkan anlamlı farklılıkların etkisini belirlemek üzere en yaygın kullanılan etki büyüklüğü istatistiği olarak eta kare (П2) kullanılmıştır. Eta kare için $\eta p^{2}<0.06$ küçük, $\eta p^{2}=0.06-0.14$ orta ve $\eta p^{2}>0.14$ ise büyük etki şeklinde ifade edilmektedir (Pallant, 2017: 269). Ayrıca araştırma bulgularında korelasyona (pearson) da yer verilmiştir.

\section{IV.Bulgular}

Tablo 1'de katılımcıların demografik özelliklerinin dağılımı yer almaktadır.

Tablo 1. Katılımcıların Demografik Özelliklerinin Dağılımı

\begin{tabular}{lcc}
\hline Özellikler & n & \% \\
\hline Cinsiyet & & \\
\hline Kadın & 56 & 36.8 \\
Erkek & 96 & 63.2 \\
\hline Medeni Durum & & \\
\hline Evli & 84 & 55.2 \\
Bekâr & 68 & 44.8 \\
\hline Eğitim Durumu & & \\
\hline Lise ve altı & 68 & 44.8 \\
Önlisans ve lisans & 84 & 55.2 \\
\hline Aylık Gelir & & \\
\hline 3000 tl ve altı & 96 & 63.1 \\
3001-5000 & 40 & 26.3 \\
5001 ve üzeri & 16 & 10.6 \\
\hline Yaş Aralığı & & \\
\hline 18-24 & 24 & 15.8 \\
25-34 & 62 & 40.8 \\
35-44 & 44 & 29.0 \\
45 ve üzeri & 22 & 14.4 \\
\hline
\end{tabular}


Bir Paydaş Olarak Turizm Ișsetmesi Çalışanlarının Kurumsal Sosyal Sorumluluk Algilarının Íncelenmesi

Tablo 1. Katılımcıların Demografik Özelliklerinin Dağılımı Devamı

\begin{tabular}{lcc}
\hline İşletme Türü & & \\
\hline Konaklama İşletmeleri & 52 & 34.2 \\
Yiyecek İçecek İşletmeleri & 82 & 54.0 \\
Seyahat Acentesi & 18 & 11.8 \\
\hline KSS Hakkında Bilgi Durumu & & \\
\hline Evet & 55 & 36.2 \\
Hayır & 97 & 63.8 \\
\hline Toplam & 152 & 100.0 \\
\hline
\end{tabular}

Tablo 1'e göre; çalışmaya katılanların; çoğunluğunun erkek, evli, önlisans veya lisans mezunu olduğu görülmektedir. Katılımcıların gelir durumları incelendiğinde katılımcıların çoğu 3000 tl ve altında aylık geliri olduğunu ifade etmiştir. Katılımcıların çoğunluğunun KSS hakkında bilgi sahibi olmadığı belirlenmiştir.

Tablo 2'de katılımcıların KKS ölçeğine ilişkin algılarının ortalama $(\overline{\mathrm{x}})$ ve standart sapma değerlerinin dağılımı yer almaktadır.

Tablo 2. Katılımcıların KKS Ölçeğine İlişkin Algılarının Ortalama ve Standart Sapma Değerlerinin Dağılımı

\begin{tabular}{|c|c|c|}
\hline Müşteriler & $\overline{\mathrm{x}}$ & ss \\
\hline $\begin{array}{l}\text { 1. Çalıştığım kurum müşteri şikâyetlerini gidermeye yönelik } \\
\text { prosedürler oluşturur. }\end{array}$ & 3.22 & 0.78 \\
\hline 2. Çalıştığım kurum müşterilerine dürüst davranır. & 3.22 & 0.74 \\
\hline $\begin{array}{l}\text { 3. Çalıştığım kurum müşterilerine ürünleri ile ilgili tam bilgi veren } \\
\text { çalışanlara sahiptir. }\end{array}$ & 3.34 & 0.76 \\
\hline $\begin{array}{l}\text { 4. Çalıştığım kurum müşterilerinin tatminini ürünlerinin } \\
\text { pazarlamasını geliştirmek için bir gösterge olarak kullanır. }\end{array}$ & 3.15 & 0.71 \\
\hline $\begin{array}{l}\text { 5. Çalıştığım kurum müşterilerinin ihtiyaçlarını anlamak için çaba } \\
\text { gösterir. }\end{array}$ & 3.23 & 0.69 \\
\hline $\begin{array}{lc} & \text { Toplam } \\
\end{array}$ & 3.16 & 0.61 \\
\hline \multicolumn{3}{|l|}{ Hissedarlar } \\
\hline 6. Çalıştığım kurum karını arttırmak için uğraşır. & 3.47 & 0.66 \\
\hline 7. Çalıştığım kurum maliyetleri üzerinde kesin olarak kontrol sağlar. & 3.17 & 0.73 \\
\hline $\begin{array}{l}\text { 8. Çalıştığım kurum ayakta kalmak ve uzun dönemde başarı elde } \\
\text { etmeyi garantilemek için uğraşır. }\end{array}$ & 3.18 & 0.74 \\
\hline
\end{tabular}

$\begin{array}{lll}\text { Toplam } & 3.24 & 0.58\end{array}$ 
Tablo 2. Katılımcıların KKS Ölçeğine İlişkin Algılarının Ortalama ve Standart Sapma Değerlerinin Dağılımı Devamı

\begin{tabular}{|c|c|c|}
\hline \multicolumn{3}{|l|}{ İş Görenler } \\
\hline 9. Çalıştığım kurum çalışanlarına adil ücret öder. & 3.11 & 0.72 \\
\hline $\begin{array}{l}\text { 10. Çalıştığım kurum işyerinde çalışanlarına güvenli bir iş ortamı } \\
\text { sunar. }\end{array}$ & 3.07 & 0.73 \\
\hline $\begin{array}{l}\text { 11. Çalıştığım kurum çalışanlarına herhangi bir ayrımcılık veya } \\
\text { istismar olmayacak biçimde tarafsız davranır. }\end{array}$ & 3.00 & 0.72 \\
\hline 12. Çalıştığım kurum çalışanlarına eğitim ve kariyer imkânı sunar. & 3.13 & 0.73 \\
\hline 13. Çalıştığım kurum çalışanlarına hoş bir çalışma ortamı sunar. & 3.06 & 0.69 \\
\hline Toplam & 3.06 & 0.61 \\
\hline \multicolumn{3}{|l|}{ Toplum } \\
\hline 14. Çalıştığım kurum sosyal sorunların çözülmesine yardım eder. & 3.11 & 0.68 \\
\hline $\begin{array}{l}\text { 15. Çalıştığım kurum bütçesinin bir kısmını toplumdaki en } \\
\text { dezavantajlı grupların durumlarını iyileştirmek amacıyla bağış ve } \\
\text { sosyal projeler için kullanır. }\end{array}$ & 2.79 & 0.79 \\
\hline $\begin{array}{l}\text { 16. Çalıştığım kurum kültürel ve sosyal etkinliklere maddi katkılar } \\
\text { sağlar. }\end{array}$ & 2.80 & 0.77 \\
\hline $\begin{array}{l}\text { 17. Çalıştığım kurum toplumda ekonomik yararlar üretmenin } \\
\text { ötesinde bir rol oynar. }\end{array}$ & 3.02 & 0.75 \\
\hline 18. Çalıştığım kurum toplumun genel refahını geliştirmeye ilgi duyar. & 3.07 & 0.68 \\
\hline $\begin{array}{l}\text { 19. Çalıştığım kurum doğaya saygı gösterilmesine ve korumaya ilgi } \\
\text { duyar. }\end{array}$ & 3.04 & 0.70 \\
\hline $\begin{array}{ll} & \text { Toplam }\end{array}$ & 2.95 & 0.61 \\
\hline \multicolumn{3}{|l|}{ Yasa ve Etik } \\
\hline $\begin{array}{l}\text { 20. Çalıştı̆ı̆m kurum yasalarla belirlenen kural ve düzenlemelere } \\
\text { daima riayet eder. }\end{array}$ & 3.57 & 0.62 \\
\hline $\begin{array}{l}\text { 21. Çalıştığım kurum ortaklar, tedarikçiler ve ilgili tüm taraflara dair } \\
\text { zorunlulukların yerine getirilmesi konusuna ilgi duyar. }\end{array}$ & 2.95 & 0.68 \\
\hline 22. Çalıştığım kurum kendini iyi kurgulanmış etik ilkelere adamıştır. & 3.01 & 0.66 \\
\hline $\begin{array}{ll}\text { Toplam } \\
\end{array}$ & 3.16 & 0.52 \\
\hline Genel KSS AlgıSı & 3.10 & 0.55 \\
\hline
\end{tabular}

Tablo 2'ye göre; katılımcıların KSS algıları alt boyut ortalamalarının yüksekten düşüğe doğru sırasıyla; "hissedarlar", "mü̈şteriler", "yasa ve etik", "iş görenler" ve "toplum" şeklinde olduğu görülmektedir. Tüm alt boyut puan ortalamalarının ortalamanın üzerinde olduğu görülmektedir.

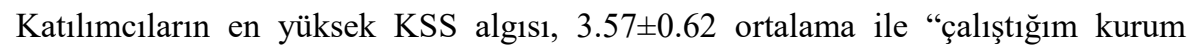
yasalarla belirlenen kural ve düzenlemelere daima riayet eder" maddesi iken, en düşük KSS algısı $2.79 \pm 0.79$ ve $2.80 \pm 0.77$ ortalamaları ile "çalışıtğım kurum bütçesinin bir 
Bir Paydaş Olarak Turizm Ișsetmesi Çalışanlarının Kurumsal Sosyal Sorumluluk Algilarının Íncelenmesi

kısmını toplumdaki en dezavantajlı grupların durumlarını iyileştirmek amacıyla bağış ve sosyal projeler için kullanır” maddesi ile “ çalıştığım kurum kültürel ve sosyal etkinliklere maddi katkılar sağlar" maddesidir (Tablo 2).

Tablo 3'de katılımcıların cinsiyet ve KSS hakkında bilgi durumları ile KSS algılarının karşılaştırılması yer almaktadır.

Tablo 3. Katılımcıların Cinsiyet ve KSS Hakkında Bilgi Durumları ile KSS Algılarının Karşılaştırılması

\begin{tabular}{|c|c|c|c|c|c|c|c|c|c|c|c|c|}
\hline \multirow{2}{*}{ Özellikler } & \multicolumn{2}{|c|}{ Müşteriler } & \multicolumn{2}{|c|}{$\begin{array}{c}\text { Hissedar } \\
\text { lar }\end{array}$} & \multicolumn{2}{|c|}{$\begin{array}{c}\text { İș } \\
\text { Görenler }\end{array}$} & \multicolumn{2}{|c|}{ Toplum } & \multicolumn{2}{|c|}{$\begin{array}{l}\text { Yasalar } \\
\text { ve Etik }\end{array}$} & \multicolumn{2}{|c|}{ KSS } \\
\hline & $\overline{\mathbf{x}}$ & SS & $\overline{\mathbf{x}}$ & SS & $\overline{\mathbf{x}}$ & SS & $\overline{\mathbf{x}}$ & SS & $\overline{\mathbf{x}}$ & SS & $\overline{\mathbf{x}}$ & SS \\
\hline \multicolumn{13}{|l|}{ Cinsiyet } \\
\hline Kadın & 3.1 & 0.6 & 3.1 & 0.6 & 3.0 & 0.6 & 2.9 & 0.6 & 3.1 & 0.4 & 3.0 & 0.5 \\
\hline Erkek & 3.2 & 0.6 & 3.3 & 0.5 & 3.1 & 0.5 & 3.0 & 0.6 & 3.2 & 0.5 & 3.1 & 0.5 \\
\hline $\begin{array}{l}\text { t; } \\
\text { p }\end{array}$ & \multicolumn{2}{|c|}{$\begin{array}{c}-1.175 \\
0.242\end{array}$} & \multicolumn{2}{|c|}{$\begin{array}{c}-1.767 \\
0.079\end{array}$} & \multicolumn{2}{|c|}{$\begin{array}{c}-1.043 \\
0.299\end{array}$} & \multicolumn{2}{|c|}{$\begin{array}{c}-1.024 \\
0.307\end{array}$} & \multicolumn{2}{|c|}{$\begin{array}{c}-1.204 \\
0.230\end{array}$} & \multicolumn{2}{|c|}{$\begin{array}{c}-1.340 \\
0.132\end{array}$} \\
\hline \multicolumn{13}{|l|}{ KSS bilgi durumu } \\
\hline Evet & 3.6 & 0.3 & 3.6 & 0.3 & 3.4 & 0.4 & 3.3 & 0.5 & 3.4 & 0.4 & 3.4 & 0.3 \\
\hline Hayır & 2.9 & 0.5 & 3.0 & 0.5 & 2.8 & 0.5 & 2.7 & 0.5 & 2.9 & 0.4 & 2.8 & 0.5 \\
\hline $\begin{array}{l}\mathbf{t} \\
\mathbf{p} \\
\eta p^{2}\end{array}$ & \multicolumn{2}{|c|}{$\begin{array}{c}8.875 \\
\mathbf{p}<\mathbf{0 . 0 0 1}\end{array}$} & \multicolumn{2}{|c|}{$\begin{array}{l}8.330 \\
\mathbf{p}<\mathbf{0 . 0 0 1}\end{array}$} & \multicolumn{2}{|c|}{$\begin{array}{c}7.340 \\
\mathbf{p}<\mathbf{0 . 0 0 1}\end{array}$} & \multicolumn{2}{|c|}{$\begin{array}{c}6.444 \\
\mathbf{p}<\mathbf{0 . 0 0 1}\end{array}$} & \multicolumn{2}{|c|}{$\begin{array}{c}6.654 \\
\mathbf{p}<\mathbf{0 . 0 0 1}\end{array}$} & \multicolumn{2}{|c|}{$\begin{array}{c}7.435 \\
\mathbf{p}<\mathbf{0 . 0 0 1}\end{array}$} \\
\hline
\end{tabular}

Katılımcıların cinsiyetine göre; müşteriler $(t=-1.175 ; p=0.242)$, hissedarlar $(t=-$ $1,767 ; p=, 079)$, iş görenler $(t=-1.043 ; p=0.299)$, toplum $(t=1.024 ; p=0.307)$, yasalar ve etik ( $\mathrm{t}=-1.204 ; p=0.230)$ alt boyutlarında ve tüm KSS ölçeği algııı $(t=-1.340 ; p=0.132)$ arasında istatistiksel olarak anlamlı farklılık saptanmamıştır $(\mathrm{p}>0.05)$. Ancak tüm alt boyutlarda erkeklerin kadınlara göre KSS algısı yüksek tespit edilmiştir (Tablo 3).

Katılımcıların KSS hakkında bilgi durumuna göre; müşteriler $(t=8.875 ; p<0.001)$, hissedarlar $(t=8.330 ; p<0.001)$, iş görenler $(t=7.340 ; p<0.001)$, toplum $(t=6.444$; $p<0.001)$, yasalar ve etik ( $t=6.654 ; p<0.001)$ alt boyutlarında ve tüm KSS ölçeği algısı $(\mathrm{t}=7.435 ; \mathrm{p}<0.001)$ arasında istatistiksel olarak anlamlı farklılık saptanmıştır $(\mathrm{p}<0.05)$. Ayrıca çıkan bu anlamlı farklılıkların tüm alt gruplarda ve tüm KSS algısında büyük etki gösterdiği belirlenmiştir. KSS hakkında bilgisi olan çalışanların KSS hakkında bilgisi olmayanlara göre KSS algılarının daha yüksek olduğu saptanmıştır. Bu doğrultuda KSS hakkında bilgi olmama durumunun KSS algısını etkilediği görülmektedir.

Tablo 4'de katılımcıların çalıştıkları işletme türü ve eğitim durumları ile KSS algılarının karşılaştırması yer almaktadır. 
Tablo 4. Katılımcıların Çalıştıkları İşletme Türü ve Eğitim Durumları ile KSS Algılarının Karşılaştırılması

\begin{tabular}{|c|c|c|c|c|c|c|c|c|c|c|c|c|}
\hline \multirow{2}{*}{ Özellikler } & \multicolumn{2}{|c|}{ Müşteriler } & \multicolumn{2}{|c|}{$\begin{array}{l}\text { Hissedar } \\
\text { lar }\end{array}$} & \multicolumn{2}{|c|}{$\begin{array}{c}\text { İş } \\
\text { Görenler }\end{array}$} & \multicolumn{2}{|c|}{ Toplum } & \multicolumn{2}{|c|}{$\begin{array}{l}\text { Yasalar } \\
\text { ve Etik }\end{array}$} & \multicolumn{2}{|c|}{ KSS } \\
\hline & $\overline{\mathbf{x}}$ & ss & $\overline{\overline{\mathbf{x}}}$ & ss & $\overline{\overline{\mathbf{x}}}$ & ss & $\overline{\mathbf{x}}$ & ss & $\overline{\overline{\mathbf{x}}}$ & ss & $\overline{\mathbf{x}}$ & ss \\
\hline \multicolumn{13}{|c|}{ Çalışılan İşletme türü } \\
\hline Konaklama & 3.2 & 0.5 & 3.3 & 0.5 & 3.0 & 0.5 & 2.9 & 0.5 & 3.2 & 0.5 & 3.1 & 0.5 \\
\hline $\begin{array}{l}\text { Yiyecek- } \\
\text { icecek }\end{array}$ & 3.1 & 0.6 & 3.2 & 0.6 & 3.1 & 0.6 & 3.0 & 0.6 & 3.1 & 0.5 & 3.1 & 0.6 \\
\hline Seyahat & 2.8 & 0.3 & 2.8 & 0.4 & 2.7 & 0.4 & 2.6 & 0.3 & 2.8 & 0.3 & 2.7 & 0.3 \\
\hline $\mathbf{F} ; \mathbf{p}$ & \multicolumn{2}{|c|}{$\begin{array}{l}2.180 \\
0.116\end{array}$} & \multicolumn{2}{|c|}{$\begin{array}{r}2.806 \\
0.063\end{array}$} & \multicolumn{2}{|c|}{$\begin{array}{l}1.475 \\
0.232\end{array}$} & \multicolumn{2}{|c|}{$\begin{array}{l}1.929 \\
0.149\end{array}$} & \multicolumn{2}{|c|}{$\begin{array}{l}1.909 \\
0.152\end{array}$} & \multicolumn{2}{|c|}{$\begin{array}{c}2.309 \\
0.103\end{array}$} \\
\hline \multicolumn{13}{|c|}{ Eğitim Durumu } \\
\hline Lise ve altı & 2.8 & 0.7 & 2.9 & 0.8 & 2.7 & 0.8 & 2.8 & 0.7 & 2.8 & 0.5 & 2.7 & 0.6 \\
\hline $\begin{array}{l}\text { On lisans } \\
\text { ve lisans }\end{array}$ & 3.5 & 0.3 & 3.4 & 0.3 & 3.1 & 0.4 & 3.1 & 0.7 & 3.2 & 0.6 & 3.2 & 0.5 \\
\hline $\begin{array}{l}\text { t; } \\
\text { p }\end{array}$ & \multicolumn{2}{|c|}{$\begin{array}{l}6.350 \\
\mathbf{0 . 0 0 4}\end{array}$} & \multicolumn{2}{|c|}{$\begin{array}{l}5.456 \\
\mathbf{0 . 0 3 4}\end{array}$} & \multicolumn{2}{|c|}{$\begin{array}{l}4.875 \\
\mathbf{0 . 0 2 4}\end{array}$} & \multicolumn{2}{|c|}{$\begin{array}{l}2.085 \\
0.067\end{array}$} & \multicolumn{2}{|c|}{$\begin{array}{l}6.102 \\
\mathbf{0 . 0 3 5}\end{array}$} & \multicolumn{2}{|c|}{$\begin{array}{l}4.113 ; \\
\mathbf{0 . 0 4 1}\end{array}$} \\
\hline$\eta p^{2}$ & \multicolumn{2}{|c|}{0.21} & \multicolumn{2}{|c|}{0.16} & \multicolumn{2}{|c|}{0.13} & \multicolumn{2}{|c|}{0.02} & \multicolumn{2}{|c|}{0.19} & \multicolumn{2}{|c|}{0.10} \\
\hline
\end{tabular}

Katılımcıların çalıştıkları işletme türlerine göre; müşteriler $(F=2.180 ; p=0.116)$, hissedarlar $(F=2.806 ; p=0.063)$, iş görenler $(F=1.475 ; p=0.232)$, toplum $(F=1.929$; $p=0.149)$, yasalar ve etik $(F=1.909 ; p=0.152)$ alt boyutlarında ve tüm KSS ölçeği algıS1 $(F=2.309 ; p=0.103)$ arasında istatistiksel olarak anlamlı farklılık saptanmamıştır $(\mathrm{p}>0.05)$ (Tablo 4).

Katılımcıların eğitim durumuna göre; müşteriler $(t=6.350 ; p=0.004)$, hissedarlar ( $t=5.456 ; p=0.034)$, iş görenler $(t=4.875 ; p=0.024)$, yasalar ve etik $(t=6.102 ; p=0.035)$ alt boyutlarında ve tüm KSS ölçeği algısı $(\mathrm{t}=4.113 ; p=0.041)$ arasında istatistiksel olarak anlamlı farklılık saptanmıştır $(\mathrm{p}<0.05)$. Ayrıca çıkan bu anlamlı farklılıklar hissedarlar, işgörenler ve yasalar ve etik alt boyutlarında geniş etki gösterirken; toplum alt boyutunda orta etki göstermiş̧tir. Tüm alt boyutlarda önlisans ve lisans eğitimi olan katılımcıların KSS algısı diğer gruplara göre yüksek olarak tespit edilmiştir (Tablo 4). Bu doğrultuda önlisans ve lisans mezunu çalışanların KSS kavramına daha hâkim olabilecekleri, eğitim sürecinde bu kavram ile karşılaşmış olabileceklerini düşündürmektedir.

Tablo 5'de katılımciların aylık gelirleri ile KSS algısı arasındaki korelasyon yer almaktadır.

Tablo 5. Katılımcıların Aylık Gelirleri ile KSS Algıları Arasındaki İlişki

\begin{tabular}{lrrrrrrr}
\hline & Müşteri & Hissedarlar & $\begin{array}{c}\text { İş } \\
\text { görenler }\end{array}$ & Toplum & $\begin{array}{c}\text { Yasa ve } \\
\text { etik }\end{array}$ & \multicolumn{1}{c}{ KSS } \\
\hline Aylık & $\mathbf{r}$ & 0.589 & 0.605 & 0.814 & 0.752 & 0.546 & 0.760 \\
Gelir & $\mathbf{p}$ & $<\mathbf{0 . 0 0 1}$ & $<\mathbf{0 . 0 0 1}$ & $<\mathbf{0 . 0 0 1}$ & $<\mathbf{0 . 0 0 1}$ & $<\mathbf{0 . 0 0 1}$ & $<\mathbf{0 . 0 0 1}$ \\
\hline
\end{tabular}

Katılımcıların aylık gelirleri ile müşteri, hissedarlar, yasa ve etik alt boyutları arasında orta ve pozitif yönlü; iş görenler, toplum alt boyutları ve toplam KSS algısı 
Bir Paydaş Olarak Turizm İşletmesi Çalışanlarının Kurumsal Sosyal Sorumluluk Algilarının İncelenmesi

arasında kuvvetli ve pozitif yönlü iliş̧ki olduğu tespit edilmiştir (Tablo 5). Bu doğrultuda çalışanların aylık geliri arttıkça KSS algılarının da arttı̆̆ı görülmektedir.

\section{Tartışma ve Sonuç}

İşletmelerin bir paydaşı olarak konaklama, yiyecek-içecek ve seyahat işletmelerinde çalışan 152 katılımcı ile yürütülen bu araştırmada; katılımcıların genel kurumsal sosyal sorumluluk algısının orta düzeyde olduğu tespit edilmiştir. KSS alt boyutlarının algısı ise en yüksekten en düşüğg; hissedarlar, müşteriler, yasa ve etik, iş görenler ve toplum şeklinde sıralanmaktadır. Çalışkan ve Ünüsan (2001)'ın yaptığ 1 araştırmada katılımcıların KSS algısının olumlu yönde olduğu belirlenmiştir. Ayrıca KSS boyutlarının en yüksekten en düşüğe ekonomik, yasal, etik ve gönüllülük boyutu şeklinde yer aldığı belirtilmiştir (Çalışkan ve Ünüsan 2011). Özdoğan ve Çolakoğlu (2018)'nun araştırmasında ise işletmelerin, en çok toplumsal ve çevresel sorumlulukları yerine getirdiği belirlenmiştir. Yurt dışında yapılan bir çalışmada, Mumbai'deki 5 yıldızlı otelde çalışan otel yöneticilerinin kurumsal sosyal sorumluluğa karşı algısının olumlu olduğu ancak çoğunlukla yapılan faaliyetlerin çevreye yönelik olduğu belirtilmiştir (Jogdand, Sawant ve Ragde, 2015:13). Yurt dışında yapılan benzer bir çalışmada ise otellerin çoğunun kurumsal sosyal sorumluluğu göz önünde bulundurmadıklarını, ancak kaynakları korumak için çeşitli tedbirler alarak çevre ile mücadele ettikleri ve KSS uygulamalarına çok az destek sağladıkları belirtilmiştir (Radwan ve Radwan, 2015: 85). Ancak bu araştırmaların aksine kurumsal sosyal sorumluluğu oldukça iyi düzeyde yerine getiren işletmelerin varlığını saptayan çalışmalar da bulunmaktadır. Park ve Levy (2014)'nin ABD'de otel işletmelerinde yaptıkları araştırmada, otel çalışanlarının KSS faaliyetleri kapsamında yeşil ve çevreci uygulamaların ötesinde ev sahibi toplumu, meslektaşları ve müşterileri kapsayan faaliyetlerin yapıldığı belirtilmiştir (Park ve Levy, 2014: 332). Tsai ve arkadaşlarının (2012) Hong Kong otellerinde yaptıkları araştırmada da katılımcıların, yaklaşık \%70'i otellerinin kurumsal sosyal sorumluluk çerçevesinde hizmet verdiğini ifade etmiştir (Tsai, Tsang ve Cheng, 2012: 1143,1152). Dolayısıyla küreselleşen dünya ile birlikte yeniliklerin ve yeni stratejilerin zorunlu kılındığ süreçte, rekabet ortamından olumsuz şekilde etkilenmemek için Trabzon bölgesindeki bu işletmelerin de kurumsal sosyal sorumluluk faaliyetlerine önem vermeleri gerekmektedir. Aksi takdirde kurumsal sosyal sorumluluk faaliyetlerinin başarılı bir şeklide yürüten rakip işletmelerin gölgesinde kaybolacakları ihtimalinin yüksek olduğu düşünülmektedir.

Yapılan bu araştırmada, katılımcılar işletmelerinde en fazla "çalıştığım kurum kârını artırmak için uğraşır" maddesinin yer aldığını ifade ederken, en az "çalıştı̆ı̆m kurum bütçesinin bir kısmını toplumdaki en dezavantajlı grupların durumlarını iyileştirmek amacıyla bağış ve sosyal projeler için kullanır" ve "çalıştığım kurum kültürel ve sosyal etkinliklere maddi kaynaklar sağlar" maddesinin yer aldığını ifade etmiştir. Bu bulgular doğrultusunda, araştırma kapsamındaki işletmelerin kârını artırmaya önem verdiği ancak bağış faaliyetleri ile kültürel ve sosyal etkinliklere önem vermediği görülmektedir. Oysaki literatürde işletmelerin kültürel, sosyal, çevresel veya yardımseverlik gibi faaliyetlere önem vermeden sadece kâr etme amacı gütmelerinin sonucunda, hedeflerine ulaşmalarının günümüz rekabet ortamında çok zor olacağı belirtilmektedir. Günümüz koşulları, artık işletmelerin varlıklarını sürdürebilmeleri için kurumsal sosyal sorumluluk 
faaliyetlerine açık olmalarını gerektirmektedir (Becan, 2011: 18; Akkoyunlu ve Kalyoncuoğlu, 2014:125; Akbaş-Tuna, Özkara ve Taş, 2019: 265).

Araştırmada katılımcıların, iş görenler açısından işletmelerin sosyal sorumluluk algılarının orta düzeyde olduğu tespit edilmiştir. Literatürde kurumsal sosyal sorumluluk felsefesini benimsemiş kurum çalışanlarının; iş doyumunun olumlu yönde etkilendiği (Lee vd., 2012: 754), işte kalma niyetini artırdığı (Çalışkan ve Ünüsan, 2011: 164 -165), motivasyonu yükselttiği (Avcı ve Akdemir, 2014: 127) belirtilmektedir. Turizm sektöründe ise çalışanlar, turizm sektörünün en önemli hizmet öğesini oluşturmaktadırlar. Çalışanların mutsuzluğu hizmet kalitesini doğrudan etkilemektedir.

Araştırmada aylık gelir arttıkça KSS algısının arttığı görülmektedir. Çalışanların memnuniyetleri ve KSS algıları açısından aldıkları maaş da önem taşımaktadır. Dolayısıyla araştırma kapsamına alınan işletmelere, iş görenlerine karşı sosyal sorumluluk faaliyetleri kapsamında yaklaşması önerilmektedir. Çünkü çalışanların verimliliği işletmenin de verimliliğini artıracaktır. Yine araştırmada katılımcıların, müşteriler açısından da sosyal sorumluluk algılarının orta düzeyde olduğu tespit edilmiştir. Literatürde kurumsal sosyal sorumluluğun müşteri memnuniyetinde olumlu etkisinin olduğu vurgulanmaktadır (Kim, Kang ve Mattila, 2012: 44; Çalışkan ve Ünüsan, 2011:155; Henderson, 2007; 231; Tsai, Tsang ve Cheng, 2012: 1144). Bu doğrultuda işletmelere müşterilerine karşı da aynı şekilde sosyal sorumluluk faaliyetleri kapsamında yaklaşması önerilmektedir.

Araştırmada ayrıca kurumsal sosyal sorumluluk hakkında bilgisi olan katılımcıların, KSS algısının daha yüksek olduğu tespit edilmiştir. Bu doğrultuda, işletme çalışanları ve işletme yöneticilerine kurumsal sosyal sorumluluk kavramı ile ilgili bilgi verilmesi gerektiği önerilmektedir. Birçok işletme çalışanı halen bu kavramdan haberdar bile değildir. Oysaki KSS, işletmelerin gelişebilmeleri ve sürdürülebilir olmaları için günümüzde artık her kurum için gerekli olmaktadır. Yine araştırmada, eğitim durumu arttıkça KSS algısının arttığı saptanmıştır. Bu da çalışanların eğitimli olmalarının olumlu yanlarını göstermektedir. Dolayısıyla turizm işletmelerinde, eğitime önem veren yöneticilerin ve iyi eğitim almış bireylerin çalıştırılması veya personelin sürekli olarak eğitim alarak kendilerini geliştirmelerinin sağlanması önerilmektedir.

Sonuç olarak katılımcıların sosyal sorumluluklarının algılarının orta düzeyde olduğu, özellikle kültürel ve sosyal sorumluluk faaliyetleri ve iş görenlere karşı faaliyetlerin yetersiz olduğu, katılımcıların çoğunluğunun KSS kavramı hakkında bilgisinin olmadığı, aylık gelir arttıkça özellikle iş gören faktörü başta olmak üzere KSS algısının arttığı, eğitim düzeyi arttıkça KSS algısının da arttığı tespit edilmiştir. Araştırmanın bu bulgularına göre turizm işletmesi çalışanlarının KSS kavramı hakkında bilgilendirilmesi gerektiği sonucuna varılmıştır. Aylık gelirin artması ile de çalışanların KSS algılarının artması KSS kavramının çalışanların memnuniyetini sağlama zorunluluğu olduğunun önemli bir bulgusu olmuştur. Aylık gelir çalışanların memnuniyeti açısından önemli bir ölçüttür. Sonuç olarak paydaş temelli kurumsal sosyal sorumluluk kavramının işletmelerin devamlılığını sağlaması, turizm sektörü paydaşlarının yenilikleri takip etmesi ve çağa ayak uydurması bakımından önemi düşünüldüğünde, turizm işletmelerinde bu kavramın yaygınlaştırılması ve ileride yapılacak olan araştırmalar için 
Bir Paydaş Olarak Turizm Ișsetmesi Çalışanlarının Kurumsal Sosyal Sorumluluk Algilarının İncelenmesi

de bu kavrama ilişkin geniş çaplı, tüm turizm paydaşlarını içeren ve işletmelere KSS kavramı hakkında eğitim içeren çalışmalar yapılması önerilmektedir.

\section{Araștırmanın Sınırlılıkları}

$\mathrm{Bu}$ araştırma yalnızca Trabzon ilinde yer alan konaklama işletmeleri, yiyecek-içecek işletmeleri ve seyahat işletmelerinde çalışanlar ile gerçekleştirilmiştir. Dolayısıyla araştırma sonuçlarımız bu evrene genellenebilir.

\section{Kaynaklar}

Akbaş Tuna, A., Özkara, Z.U. ve Taş, A. (2019). Paydaş temelli kurumsal sosyal sorumluluk ölçeğinin Türkçeye uyarlanması çalışması. Ankara Hacı Bayram Veli Üniversitesi İktisadi ve İdari Bilimler Fakültesi Dergisi, 21(2), 263-285.

Akkoyunlu, G.Ş. ve Kalyoncuoğlu, S. (2014). İşletmelerin kurumsal sosyal sorumluluk çalışmalarının marka algısı üzerine etkisinin değerlendirilmesi. Niğde Üniversitesi İktisadi ve İdari Bilimler Fakültesi Dergisi, 7(3), 125-144.

Aktan, C.C. (2007). Kurumsal sosyal sorumluluk işletmeler ve sosyal sorumluluk. İstanbul: İGIAD Yayını, Veste Ofset, http://www.canaktan.org/can-aktankitaplar/kurumsal-sosyal_sorumluluk.pdf

Avc1, N. ve Akdemir, İ. (2014). The 1mpact of corporate social responsibility on job satisfaction in hotels. Ege Academic Review, 14(1), 125-135.

Baniya, R., Thapa, B., \& Kim, M.S. (2019). Corporate social responsibility among travel and tour operators in Nepal. Sustainability, 11(10), 2771-2785.

Becan, C. (2011). Kurumsal sosyal sorumluluk kavramının paydaş teorisi ve iletişim yaklaşımı açısından değerlendirilmesi: bankaların basın bültenlerine yönelik bir içerik analizi. Selçuk Iletişim, 7(1), 16-35.

Blinova, E., Gregoric, M., Elena, D., Romanova, MM. (2018). Corporate social responsibility in tourism: 1nternational practices. European Research Studies Journal, 21(3), 636-647.

Boğan, E., Ulama, Ş. ve Sarışı1k, M. (2016). Zincir ve grup otel işletmelerinin kurumsal sosyal sorumluluk faaliyetlerini duyurmada web sitelerinin etkinliği üzerine bir araştırma: Türkiye Örneği. International Conference On Eurasian Economies, 727733.

Brunton, M., Eweje, G., ve Taskin, N. (2015). Communicating corporate social responsibility to internal stakeholders: walking the walk or just talking the talk? Business Strategy and the Environment, 1-40.

Çakmak, V. ve Aktan, E. (2018). Sosyal sorumluluğun turizm faaliyetlerindeki rolü üzerine bir inceleme. Gümüşhane Üniversitesi İletişim Fakültesi Elektronik Dergisi, 6(1), 172-193. 
Çalışkan, O. ve Ünüsan, Ç. (2011). Otel çalışanlarının kurumsal sosyal sorumluluk algısının iş tatmini ve işte kalma niyetine etkisi. Anatolia Turizm Araştırmaları Dergisi, 22(2), 154-166.

Dennis, O. (2015). An African Paradigm for Corporate Social Responsibility. Journal of Management and Training for Industries, 2(2), 41-55.

Freeman, RE. \& Dmytriyev, S. (2017). Corporate social responsibility and stakeholder theory: learning from each other. SYMPHONYA Emerging Issues in Management, 1, 7-15.

Gül- Özdoğan, Y. ve Çolakoğlu, O. (2018). Otel İşletmelerinde Kurumsal Sosyal Sorumluluk Uygulamaları: Kuşadası Örneği, International Journal of Contemporary Tourism Research, 2(2), 76-91.

Güven, S. (2016). Kurumsal İletişim Bağlamında Kurumsal Sosyal Sorumluluk ve Etik İlişkisi, Akdeniz İletişim, 26, 133-154.

Henderson, J.C. (2007). Corporate social responsibility and tourism: hotel companies in Phuket, Thailand, After the Indian Ocean Tsunami. Hospitality Management, 26, 228-239.

Isma1l, M. (2009). Corporate social responsibility and its role in community development: an international perspective. The Journal of International Social Research, 2(9), 199-209.

Jogdand, B., Sawant, M., ve Ragde, R. (2015). Ethics and corporate social responsibility in hotel industry: a study of attitudes and perception of managers. Tourism Inclusive Growth \& Sustainable Dvevelopment, (pp.593-606). Bharati Publication.

Kakabadse, NK., Rozuel, C. \& Lee-Davies L. (2005). Corporate social responsibility and stakeholder approach: a conceptual Review. International Journal of Business Governance and Ethics, 1(4), 277-302.

Kang, K.H., Lee, S. \& Huh, C. (2010). Impacts of positive and negative corporate social responsibility activities on company performance in the hospitality Industry. International Journal of Hospitality Management, 29, 72-82.

Kim, E.E.K., Kang, J. \& Mattila A.S. (2012). The impact of prevention versus promotion hope on CSR activities, International Journal of Hospitality Management, 31,43-51.

Lee, Y.K, Kim, Y.S., Lee, K.H, \& Li, D. (2012). The impact of CSR on relationship quality and relationship outcomes: a perspective of service employees. International Journal of Hospitality Management, 31(3), 745-756.

Lorca, P. \& Garcia-Diez, J. (2004). The relation between firm survival and the achievement of balance among its stakeholders: an analysis. International Journal of Management, 21(1), 93-99.

Lund-Durlacher, D. (2015). Corporate Social Responsibility and Tourism, CSR, Sustainability, Ethics \& Governance, 59-73. 
Bir Paydaş Olarak Turizm Ișsetmesi Çalışanlarının Kurumsal Sosyal Sorumluluk Algilarının İncelenmesi

Miles, M.P. \& Munilla, L.S. (2004). The potential impact of social accountability certification on marketing: a short note. Journal of Business Ethics, 50(1), 1-11.

Nikolova, V. \& Arsić, S. (2017). The stakeholder approach in corporate social responsibility. Engineering Management, 3(1), 24-35.

Önder, Ş. ve Kaya, E. (2018). İşletmelerin kurumsal sosyal sorumluluk uygulamalarında kurumsal yönetim yapılarının etkisi: BİST 100 üzerine bir uygulama. Muhasebe ve Finansman Dergisi, (78), 155-170.

Pallant, J. (2017). SPSS kullanma klavuzu SPSS ile adım adım veri analizi. (çev: Sibel Balcı ve Berat Ahi). Anı yayıncılık, 2. Baskı.

Park, S.Y., \& Levy, S. (2014). Corporate social responsibility: perspectives of hotel frontline employees. International Journal of Contemporary Hospitality Management, 26(3), 332-348.

Paskova, M. \& Zelenka, J. (2018). How crucial is the social responsibility for tourism sustainability? Social Responsibility Journal, 15(4), 534-552.

Radwan, H. R. I. (2015). The 1mpact of corporate social responsibility on employees in the hotel sector. International Journal of Tourism \& Hospitality Reviews, 2(1), 8596.

Reinig, C.J. \& Tilt, CA. (2009) Corporate social responsibility 1ssues in media releases: a stakeholder analysis of Australian Banks. Issues in Social and Environmental Accounting, 2(2), 176-197.

Sağır, M. ve Türkeri, İ. (2015). Turizm işletmelerinde stratejik boyutları ile kurumsal sosyal sorumluluk uygulamaları: örnek incelemeler. Süleyman Demirel Üniversitesi Sosyal Bilimler Enstitüsü Dergisi, 2(22), 283-314.

Su, L., \& Swanson, S.R. (2017). The effect of destination social responsibility on tourist environmentally responsible behavior: compared analysis offirst-time and repeat tourists. Tourism Management, 60, 308-321.

Taghian, M., D'Souza C. \& Polonsky, M. (2015). A stakeholder approach to corporate social responsibility. Reputation and Business Performance Social Responsibility Journal, 11(2), 340-363.

Tsai, H., Tsang, N. K. F., \& Cheng, S. K. Y. (2012). Hotel employees' perceptions on corporate social responsibility: The Case of Hong Kong. International Journal of Hospitality Management, 31(4), 1143-1154.

Türker, N. ve Uçar M. (2013). Konaklama işletmelerinin sosyal sorumlulukları. İşletme Araştırmaları Dergisi, 5(3), 155-183.

Usta, M. ve Pırnar, İ. (2009). İtibar yönetimi kapsamında sosyal sorumluluk. Pazarlama ve İletişim Kültürü Dergisi, 8(28), 4-13.

Yorulmazer, G. ve Doğan, O. (2017). Turizm işletmelerindeki kurumsal sosyal sorumluluk uygulamalarının satın alma niyeti üzerindeki etkileri: turistlere yönelik 
bir araştırma. Gümüşhane Üniversitesi Sosyal Bilimler Enstitüsü Elektronik Dergisi, 8(21), 49-75.

Zink, K.J. (2005). Stakeholder orientation and corporate social responsibility as a precondition for sustainability. Total Quality Management and Business Excellence, 16(8/9), 1041-1052. 